\title{
Comparison of 5 Versus 7-Day Ovsynch + Progesterone Releasing Intravaginal Device Protocols (PRID) and a Modified G7G with an Option of Heat Detection Protocol for 1st Service in Lactating Dairy Cows
}

\author{
Christos Brozos ${ }^{1}$, Evangelos Kiossis ${ }^{1}$, Savvas Hatzieffraimidis ${ }^{1}{ }^{\mathbb{D}}$, Anastasia Praxitelous ${ }^{1}$, Ioannis Gouvias ${ }^{2}$, \\ Vasileios Kanoulas ${ }^{2}$ and Georgios Tsousis $1, * \mathbb{D}$ \\ 1 Clinic of Farm Animals, Faculty of Veterinary Medicine, Aristotle University of Thessaloniki, \\ 54627 Thessaloniki, Greece; brozos@vet.auth.gr (C.B.); ekiossis@vet.auth.gr (E.K.); \\ cdsavvas@vet.auth.gr (S.H.); praxitea@vet.auth.gr (A.P.) \\ 2 CEVA Hellas, 16341 Ilioupoli, Greece; giannis.gouvias@ceva.com (I.G.); vasilis.kanoulas@ceva.com (V.K.) \\ * Correspondence: tsousis@vet.auth.gr; Tel.: +30-2310-994-466
}

Citation: Brozos, C.; Kiossis, E.; Hatzieffraimidis, S.; Praxitelous, A.; Gouvias, I.; Kanoulas, V.; Tsousis, G. Comparison of 5 Versus 7-Day Ovsynch + Progesterone Releasing Intravaginal Device Protocols (PRID) and a Modified G7G with an Option of Heat Detection Protocol for 1st Service in Lactating Dairy Cows. Animals 2021, 11, 2955. https:// doi.org/10.3390/ani11102955

Academic Editor: Gianluca Neglia

Received: 7 September 2021

Accepted: 12 October 2021

Published: 13 October 2021

Publisher's Note: MDPI stays neutral with regard to jurisdictional claims in published maps and institutional affiliations.

Copyright: (c) 2021 by the authors. Licensee MDPI, Basel, Switzerland. This article is an open access article distributed under the terms and conditions of the Creative Commons Attribution (CC BY) license (https:// creativecommons.org/licenses/by/ $4.0 /)$.
Simple Summary: The efficacy of two timed-AI protocols (5- and 7- Ovsynch + PRID) and a modified G7G protocol, that included intermediate heat detection, was evaluated. There was no difference in Pregnancy per AI between the two timed-AI protocols. The modified G7G protocol resulted in higher P/AI compared to the pooled data from the two TAI protocols. As a conclusion, enhancing detection of estrus within a synchronization protocol, by increasing the proportion of cows eligible to show estrus (e.g., by pre-synchronization) or by using activity-monitoring systems, could improve the reproduction indices of dairy cows.

Abstract: The aim of this study was to evaluate the efficacy of two timed-AI (TAI) protocols (Group G5D, GnRH and PRID -5d- PGF2a -1d- PGF2a -1d- GnRH, $n=105$ and Group G7D, GnRH and PRID-7d- PGF2a -1d- PGF2a -1d- GnRH, $n=98$ ) and a modified G7G protocol combining heat detection (HD) and AI or TAI if HD failed (Group HD, GnRH and PRID -7d- PGF2a -1d- PGF2a -5d- HD or 5d TAI if no HD, $n=92$ ). Pregnancy per AI (P/AI) did not differ between G5D and G7D protocol (G5D: 33.8\% vs. G7D: 35.2\%, P = 0.85). Cows assigned to G5D and G7D group were pooled as TAI group (GTAI) and further compared to GHD. Within the GHD, more primiparous cows exhibited estrous signs compared to multiparous cows $(70.4 \%$ vs. $46.2 \%, \mathrm{P}=0.03)$. Furthermore, 49 cows $(53.3 \%)$ were served after HD, whereas 43 cows $(46.7 \%)$ were served after TAI. There was no difference in P/AI between cows served after HD (51.6\%) or after TAI (43.0\%, P = 0.49). GHD showed higher $\mathrm{P} / \mathrm{AI}$ at 1 st service compared to GTAI (49.1\% vs. $36.4 \%, \mathrm{P}=0.04$ ), whilst, median days to pregnancy did not differ between the two groups. Overall, $\mathrm{P} / \mathrm{AI}$ of primiparous cows tended to be better in comparison with multiparous cows $(48.3 \%$ vs. $37.2 \%, \mathrm{P}=0.06)$. In conclusion, there was no significant difference regarding the efficacy of 5- and 7-day Ovsynch + PRID protocols. Moreover, a modified G7G protocol, with intermediate heat detection, resulted in overall better P/AI compared to TAI protocols and appears as a promising strategy to optimize estrus detection for 1st AI.

Keywords: dairy cows; Ovsynch; progesterone; timed AI

\section{Introduction}

During the past decades, genetic progress, and the enhancement of management in dairy cattle have led to an increased milk production, Dry Matter Intake (DMI) and metabolism accompanied with an increased liver function. The enhanced metabolism can impair concentrations and half-life of reproductive hormones [1], leading eventually to reduced estrus expression and fertility. The development of synchronization protocols, 
that regulate ovulation and lead to Timed Artificial Insemination (TAI), has been used to achieve increased pregnancy rates in dairy cows [2].

The most popular protocols for TAI used for the first post-partum service are PresynchOvsynch [3], G6G or G7G and Double Ovsynch [4,5]. These or similar protocols are now the core of reproductive management programs in dairy cattle farms to optimize fertility and submission rate. Improvements of our knowledge on ovarian structures and the hormonal patterns that regulate them, has led to numerus modifications of the classical Ovsynch protocol proposed by Pursley, et al. [6], to further increase pregnancy rates. Such modifications include the addition of progesterone releasing intravaginal devices (PRID) at the time of the first GnRH administration, a PGF2 $\alpha$ administration 5 or 7 days after the initial GnRH (together with PRID removal) and the addition of a second PGF2 $\alpha 24 \mathrm{~h}$ apart $[7,8]$.

The inclusion of a progesterone releasing intravaginal device in the Ovsynch protocol has positive effects on pregnancy per $\mathrm{AI}(\mathrm{P} / \mathrm{AI})$. The increment of $\mathrm{P} 4$ concentration following PRID insertion has shown to increase P/AI especially in non-cycling or anestrus cows or cows with low progesterone at the time of PGF $2 \alpha$ treatment of an Ovsynch protocol [9]. Hence, protocols have been developed that include PRID insertion between the first GnRH treatment and the PGF2 $\alpha$ treatment and PRID removal concurrently with the PGF $2 \alpha$ injection after 5 or 7 days. An addition of a second PGF2 $\alpha$ treatment after 24 h, can increase the percentage of cows that present luteal regression and enhance synchronization efficiency [8]. Furthermore, this extra PGF2 $\alpha$ treatment offers the possibility of hastening the time between the $2 \mathrm{GnRH}$ injections, especially when the first one induces ovulation and leads to the formation of a new CL, as expected in pre-synchronization protocols [10]. Nevertheless, the efficiency of the 5- vs. the 7-day protocol for first post-partum AI has been studied only for a Co-Synch version [10]. Moreover, studies have shown that the ideal time frame of the estrus cycle for the initiation of the Ovsynch protocol is between 5 and 9 days [11]. A study conducted by Bello, et al. [12] has shown an increment in ovulatory response to the first $\mathrm{GnRH}$, which improves the efficiency of the synchronization protocol, if the Ovsynch protocol starts during days 6 and 7 of the estrus cycle. Based on this knowledge, pre-synchronization protocols have been developed, such as the Double Ovsynch protocol, to further synchronize the stage of the estrus cycle at initiation of Ovsynch [5].

Nevertheless, AI after detection of estrus remains popular, especially in smaller farms. The wide implementation of precision dairy monitoring technology has increased the accuracy of estrus detection [13], making AI after natural estrus more efficient nowadays. However, Ovsynch protocols reduce estrus expression due to the 2nd GnRH injection which often leads to ovulation before estrus. As a result, Ovsynch protocols, applied to manipulate ovarian activity in high yielding dairy cows, and estrus detection, to optimize insemination success, could not be used concomitantly, but in a potential collaboration. This arrangement should be investigated to pose an appealing reproductive protocol.

The objective of this study was to investigate the efficacy of three hormonal protocols for the 1st post-partum (p.p.) AI in dairy cows. The basic purpose of the experiment was to compare a 5- vs. a 7-day Ovsynch + PRID protocol for their efficiency on the 1st p.p. TAI and the second to evaluate the efficacy of a modified G7G protocol with an option of an AI based on estrus detection.

\section{Materials and Methods}

\subsection{Animals and Experimental Design}

The experiment was performed in two commercial dairy farms (one in Macedonia and one in Thessaly region, Greece) including 200 and 140 milking cows, respectively, and an annual herd milk production of 10,500 and 11,500 kg of milk. Cows were housed in free stalls with unrestricted access to water and feed and were milked twice daily. Cows with reproductive disorders such as severe dystocia, clinical mastitis, or lameness were excluded from the study. 
At 50 days in milk (DIM), a total of 315 healthy cows were blocked by parity and randomly assigned to one of the three protocols ( $n=105$ per group), initiated on a weekly basis. Cows in group 5D and 7D, were assigned to a TAI protocol (Figure 1). Specifically, all cows received an intramuscular injection of $25 \mathrm{mg}$ Dinoprost $\left(5 \mathrm{~mL}\right.$ of Cevaprost ${ }^{\circledR}$, CEVA Santé Animal, Libourne, France) at $56 \pm 3$ DIM (G5D) and $54 \pm 3$ DIM (G7D), followed by one administration of $100 \mathrm{mg}$ Gonadorelin $\left(2 \mathrm{~mL}\right.$ of Ovarelin ${ }^{\circledR}$, CEVA Santé Animal, France) 2 days later ( $58 \pm 3$ for G5D, $56 \pm 3$ for G7D, pre-synch PGF2 $\alpha$ and GnRH, respectively, Figure 1). Seven days later, a GnRH (2 mL of Ovarelin $\left.{ }^{\circledR}\right)$ treatment and a progesterone releasing intravaginal device (PRID ${ }^{\circledR}$, CEVA Santé Animal, France) was inserted in the animals of both groups. The PRID ${ }^{\circledR}$ remained in situ for 5 (G5D) or 7 days (G7D). On the day of PRID ${ }^{\circledR}$ removal $(70 \pm 3$ DIM) and the following one (71 \pm 3 DIM) all animals received 2 PGF2 $\alpha$ injections ( $5 \mathrm{~mL}$ of Cevaprost ${ }^{\circledR}$ ). Thirty-six hours after the second PGF2 $\alpha$ administration (72 \pm 3 DIM) cows were given a 2nd dose of GnRH ( $2 \mathrm{~mL}$ of Ovarelin $\left.{ }^{\circledR}\right)$ and sixteen hours later (73 \pm 3 DIM), timed artificial insemination (TAI) took place.

Cows in Group HD (GHD, $n=105$ ) from days 54 to 63 followed the pre- and synchronization protocol of G7D (Figure 1). These cows were not supplemented with the progesterone releasing intravaginal device. Seven and 8 days later $(70 \pm 3$ and $71 \pm 3$ DIM, respectively) cows were injected with $5 \mathrm{~mL}$ of Cevaprost ${ }^{\circledR}$. The following 5 days (72-76 \pm 3 DIM), cows that were detected in estrus by the farm personnel were inseminated following the AM$\mathrm{PM}$ rule. On day $77 \pm 3 \mathrm{DIM}$, the cows of GHD that were not detected in estrus received a GnRH $\left(2 \mathrm{~mL}\right.$ of Ovarelin $\left.{ }^{\circledR}\right)$ injection and a PRID ${ }^{\circledR}$ was inserted. The device remained in place for 5 days, followed by two injections of PGF2 $\alpha 24 \mathrm{~h}$ apart (82 and $83 \pm 3$ DIM). Thirty-six hours after the 2nd PGF administration (72 \pm 3 DIM) cows received GnRH and TAI as previously described for the G5D and G7D. Pregnancy diagnosis was performed by transrectal ultrasonography with a 5-MHz linear-array transducer (Honda HS-101V; Honda electronics Co., Ltd., Toyohashi, Japan) at $33 \pm 3$ days post AI. A second pregnancy diagnosis was carried out via transrectal palpation at $80 \pm 3$ days post AI to detect pregnancy loss. All cows of G5D were eligible for analysis, whereas 7 cows were excluded from G7D ( 3 lost the devices, 2 became ill and 2 lacked sufficient documentation) and 13 cows were removed from GHD ( 5 due to healthy reasons and 8 due to insufficient documentation i.e., were lost in follow up from the farmers). Thus, the analysis was conducted with sample size of 105, 98 and 92 for G5D, G7D and GHD, resp.

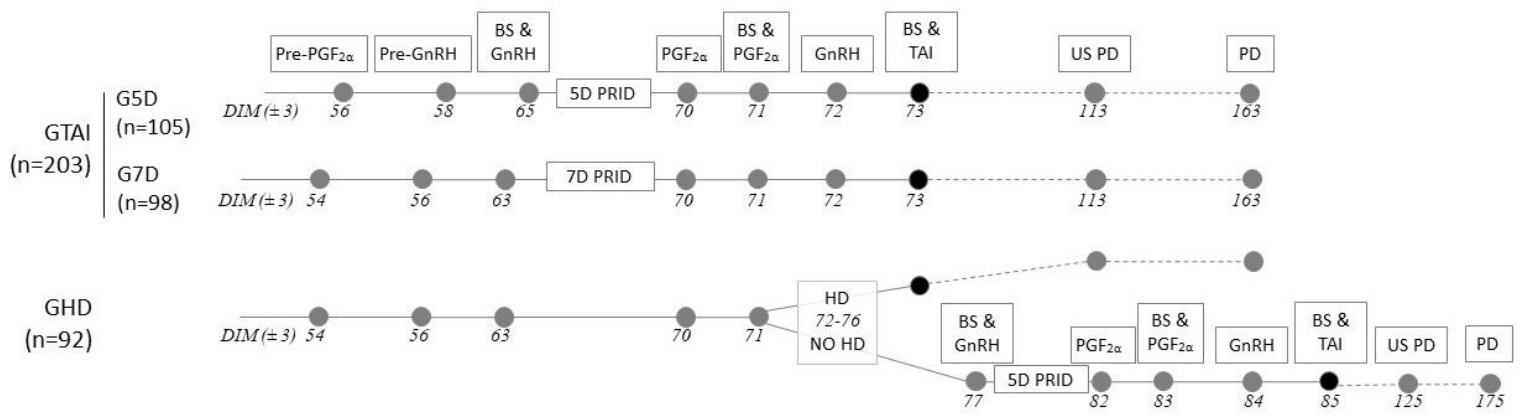

Figure 1. Timeline of the experimental design including two Timed Artificial Insemination (TAI) protocols (G5D and G7D) and a protocol combining AI after heat detection (GHD) with TAI if HD failed. BS = blood sample; US = transrectal ultrasonography; $\mathrm{PD}$ = pregnancy diagnosis; $\mathrm{PRID}$ = progesterone releasing intravaginal device.

\subsection{Blood Collection and Hormonal Assay}

A random subset of cows ( $n=48,50$ and 38 for G5D, G7D and GHD, resp.) was used to collect blood samples from the coccygeal vein after disinfection of the area. The samples were stored on ice until centrifuged $\left(3500 \times g\right.$ for $15 \mathrm{~min}$ at $4{ }^{\circ} \mathrm{C}$ ) within $60 \mathrm{~min}$ after collection, and then plasma was stored at $-20^{\circ} \mathrm{C}$ until hormone analyses. Blood samples were collected at: (a) day 63 or $65 \pm 3$ (Figure 1), and (b) day $71 \pm 3$, for cows from all groups, and (c) at TAI only for animals of G5D and G7D. Serum P4 concentration 
was evaluated by solid phase RIA, from unextracted sera, with the use of a commercially available radioimmunoassay kit (IMMUNOTEC, Prague, Czech Republic). The lower detection limit was $0.03 \mathrm{ng} / \mathrm{mL}$, and the intra- and inter-assay coefficients of variation (CVs) was $<10 \%$. A cow with plasma P4 levels $\leq 1 \mathrm{ng} / \mathrm{mL}$ was documented as having no luteal activity (LA).

\subsection{Statistical Analysis}

Total sample size was estimated with $\mathrm{G}^{*}$ power software (Heinrich-Heine-Universität Düsseldorf, Düsseldorf, Germany). The analysis was performed with Fischer's exact test for two independent groups (GTAI and GHD). To conduct this analysis, we specified a difference of $15 \%$ in the P/AI (0.35 vs. 0.50 ), a significance level of 0.05 , and a power of 0.80 . Further statistical analysis was performed using the Statistical Analysis System v9.3 (SAS Institute, Cary, NC, USA). In a first step, differences in binary variables were evaluated by chi-square analysis (PROC FREQ).

Generalized linear mixed models using PROC GLIMMIX were used to verify the effect of a set of variables on binary outcomes. The included fixed effects during modelling were group (G5D vs. G7D, for the initial analysis, and GTAI, which derived from pooling of G5D with G7D, vs. GHD, for the subsequent analysis), parity (primi- vs. multiparous), season (winter, November to April, vs. summer, May to October) and milk yield (low vs. high, based on median value of G5D and G7D, for the initial analysis, and of GTAI and GHD for subsequent analysis). Farm was included as a random effect. All two-way interactions with the group were included into the models. Backward stepwise selection with level of stay of 0.10 was used. Pairwise comparisons were performed using the LSMeans statement. Cows of group HD had different submission to AI compared to GTAI cows, as they were given two chances to be inseminated (after HD or TAI if HD failed). To adjust this effect, the rate of becoming pregnant and the median days to pregnancy for GHD and GTAI were evaluated using the Kaplan-Meyer survival curves (PROC LIFETEST) and Cox's proportional hazards regression model (PROC PHREG). Due to our study design, that focused solely on 1st AI success, endpoint for a cow to become pregnant was set to $100 \mathrm{~d}$. Results are presented as means or LSMeans \pm SEM, unless stated otherwise. Differences were statistically significant at $\mathrm{P}<0.05$ and as a tendency at $0.05 \leq \mathrm{P}<0.10$.

\section{Results}

The mean and median lactation number and milk yield for all cows were $1.66 \pm 0.03$, 2 and $37.9 \pm 0.43,38 \mathrm{~kg}$, respectively, and did not differ between the three groups (both $\mathrm{P}>0.10$ ). Overall P/AI was $38 \%$ (112 out of 295 cows) and pregnancy loss $8.9 \%$ (10 out of 112 cows, evenly distributed between groups).

\subsection{Comparison of the Two TAI Protocols}

Regarding the comparison between the two TAI protocols, there was no difference on P/AI (G5D: $33.8 \%$ vs. G7D: $35.2 \%, P=0.85$ ). Additionally, no significant interactions between protocols and parity, season or milk yield were detected (all $\mathrm{P}>0.40$ ). In these two groups of cows only parity tended $(\mathrm{P}=0.06)$ to be different for $\mathrm{P} / \mathrm{AI}$ (primiparous: $39.7 \%$ vs. multiparous cows: $26.9 \%$, Table 1 ). G5D did not differ compared to group G7D regarding proportion of cows with no luteal activity at initiation of the protocol, after the 1st injection of PGF2 $\alpha$ or at the time of AI (all P >0.20, Table 2).

There was no difference in P/AI between cows with LA $(n=86)$ versus no LA $(n=12)$ at initiation of the protocol $(38.4 \%$ vs. $33.3 \%$, resp., $\mathrm{P}=0.74)$. The same was true regarding cows with LA $(n=78)$ or no LA $(n=20)$ after the 1 st PGF $2 \alpha(41.0 \%$ vs. $25.0 \%$, resp., $\mathrm{P}=0.19)$. Cows with LA at $\mathrm{AI}(n=16)$ tended to have lower $\mathrm{P} / \mathrm{AI}$ compared to cows with no LA at $\mathrm{AI}(n=82)(18.8 \%$ vs. $41.5 \%$, resp., $\mathrm{P}=0.08)$. Twelve cows $(12.2 \%)$ showed no decrease in the P4 values from the day after the 1st PGF2 $\alpha$ to AI (luteal regression). None of these cows conceived compared to $43 \%$ of the cows, in which a decrease in P4 values was observed $(\mathrm{P}=0.004)$. The proportion of cows with no luteal regression was 
not influenced by treatment $(15.5 \%$ in G5D vs. $15.2 \%$ in G7D, $\mathrm{P}=0.96)$, by parity $(18.4 \%$ in primi- vs. $12.3 \%$ in multiparous, $\mathrm{P}=0.43)$ nor by milk yield $(15.0 \%$ in low yielders vs. $15.7 \%$ in high yielders, $\mathrm{P}=0.93$ ). However, season tended to affect the proportion of cows with no luteal regression $(8.2 \%$ in winter vs. $19.0 \%$ in summer, $\mathrm{P}=0.10)$.

Table 1. LS means of pregnancy per AI (P/AI) at 1st service and P-values of the variables under consideration for the comparison between groups 5D and 7D.

\begin{tabular}{cccccc}
\hline Variable & Class & $\boldsymbol{n}$ & P/AI, $\%$ & $\boldsymbol{F}$-Value & $p$-Value \\
\hline Treatment & G5D & 105 & 33.8 & 0.04 & 0.85 \\
& G7D & 98 & 35.2 & & \\
Season & Summer & 77 & 39.3 & 1.93 & 0.17 \\
& Winter & 126 & 29.7 & & \\
Parity & LN $=1$ & 72 & 39.7 & 3.46 & 0.06 \\
& LN $>1$ & 131 & 26.9 & & \\
Milk Yield & Low $(<37.3 \mathrm{~kg})$ & 101 & 35.0 & 0.02 & \\
& High $(\geq 37.3 \mathrm{~kg})$ & 102 & 34.0 & & \\
& & & & & \\
\hline
\end{tabular}

Table 2. Proportion of cows with $\mathrm{P} 4 \leq 1 \mathrm{ng} / \mathrm{mL}$ at initiation of the protocol, after the 1st injection of PGF $2 \alpha$ and at the time of $\mathrm{AI}$ in cows synchronized with a 5- and a 7-day protocol (Group 5D, $n=48$ and $7 \mathrm{D}, n=50$, respectively).

\begin{tabular}{cccc}
\hline Time Point and Variable & Group 5D & Group 7D & $p$-Value \\
\hline $\begin{array}{c}\text { Initiation of protocol } \\
\text { P4 } \leq 1 \mathrm{ng} / \mathrm{mL}(\%)\end{array}$ & 10.4 & 14.0 & 0.59 \\
$\quad \begin{array}{c}\text { After } 1 \mathrm{st} \mathrm{PGF2a} \\
\mathrm{P} 4 \leq 1 \mathrm{ng} / \mathrm{mL}(\%)\end{array}$ & 18.8 & 22.0 & 0.69 \\
$\quad$ At AI & & & \\
$\mathrm{P} 4 \leq 1 \mathrm{ng} / \mathrm{mL}(\%)$ & 79.2 & 88.0 & 0.24 \\
\hline
\end{tabular}

\subsection{Comparison of TAI vs. HD-TAI Protocols}

Based on these findings, data from the two TAI protocols were pooled to form group TAI (GTAI, $n=203)$. GTAI showed lower P/AI compared to GHD (36.4\% vs. 49.1\%, resp., $\mathrm{P}=0.04$ ). Primiparous cows tended to have higher $\mathrm{P} / \mathrm{AI}$ compared to multiparous cows (48.3\% vs. $37.2 \%$, resp., $\mathrm{P}=0.06$ ). Season and milk yield had no significant effect on $\mathrm{P} / \mathrm{AI}$ (both P > 0.70). However, an interaction between season and treatment was evident $(\mathrm{P}=0.09)$, as GTAI showed better $\mathrm{P} / \mathrm{AI}$ in the summer $(41.5 \%)$ compared to winter $(31.2 \%)$ while cows in the GHD had better fertility in the winter compared to summer (54.3\% vs. $44.0 \%$, resp., Table 3$)$. There was no difference between GTAI $(n=98)$ and GHD $(n=38)$ regarding the proportion of cows with no LA $(12.2 \%$ vs. $13.2 \%$, resp., $\mathrm{P}=0.89)$ at initiation of the protocol. Regarding P4 values after the 1st PGF2 $\alpha$, GHD showed a higher proportion of cows with no LA (36.8\%) compared to GTAI $(20.4 \%, \mathrm{P}=0.05)$. The rate of becoming pregnant (hazard ratio $1.4 ; 95 \% \mathrm{CI} 0.9-2.0, \mathrm{P}=0.11$ ) and the median days to pregnancy (73 vs. 75, resp.) did not differ between GTAI and GHD (Figure 2).

Within Group HD, 49 cows (53.3\%) exhibited estrus and were served, whereas 43 cows $(46.7 \%)$ were not detected in estrus and received the PRID synch protocol for fixed-TAI. There was no difference in P/AI between the cows served after HD (51.6\%) or after TAI $(43.0 \%, \mathrm{P}=0.49)$. From the cows with no LA at initiation of the protocol $(n=5), 80 \%$ exhibited estrus $(n=4)$, whereas in cows with LA this proportion was $48.5 \%$ (17 out of 33 , $\mathrm{P}=0.19)$. After the 1 st PGF $2 \alpha$, the proportion of cows with $\mathrm{P} 4<1 \mathrm{ng} / \mathrm{mL}$ was equal in cows that were and were not detected in estrus (35.0\% vs. 38.9\%, P = 0.80). Within the HD group, more primiparous cows were detected in estrus compared to multiparous cows 
(70.4\% vs. $46.2 \%, \mathrm{P}=0.03)$. No effect of season $(61.2 \%$ in winter vs. $53.0 \%$ in summer, $\mathrm{P}=0.45)$ or milk yield $(56.5 \%$ in low yielders vs. $57.6 \%$ in high yielders, $\mathrm{P}=0.92)$ was found regarding the proportion of cows detected in estrus.

Table 3. LS means of pregnancy per $\mathrm{AI}(\mathrm{P} / \mathrm{AI})$ at 1st service and P-values of the variables under consideration for the comparison between groups TAI and HD.

\begin{tabular}{cccccc}
\hline Variable & Class & $n$ & P/AI, $\%$ & F-Value & $p$-Value \\
\hline Treatment & GTAI & 203 & 36.4 & 4.27 & 0.04 \\
& GHD & 92 & 49.1 & & \\
Season & Summer & 114 & 42.3 & 0.00 & 0.95 \\
& Winter & 181 & 42.7 & & \\
Parity & & & & 3.50 & 0.06 \\
& LN $=1$ & 99 & 48.3 & & \\
Milk Yield & LN $>1$ & 196 & 37.2 & 0.13 & 0.72 \\
& Low $(<38 \mathrm{~kg})$ & 141 & 43.7 & & \\
Treatment & High $(\geq 38 \mathrm{~kg})$ & 154 & 41.4 & & \\
$\times$ Season & & & & 2.74 & \\
& GTAI Summer & 77 & 41.5 & & \\
& GTAI Winter & 126 & 31.2 & & \\
& GHD Summer & 37 & 44.0 & & \\
& GHD Winter & 55 & 54.3 & &
\end{tabular}

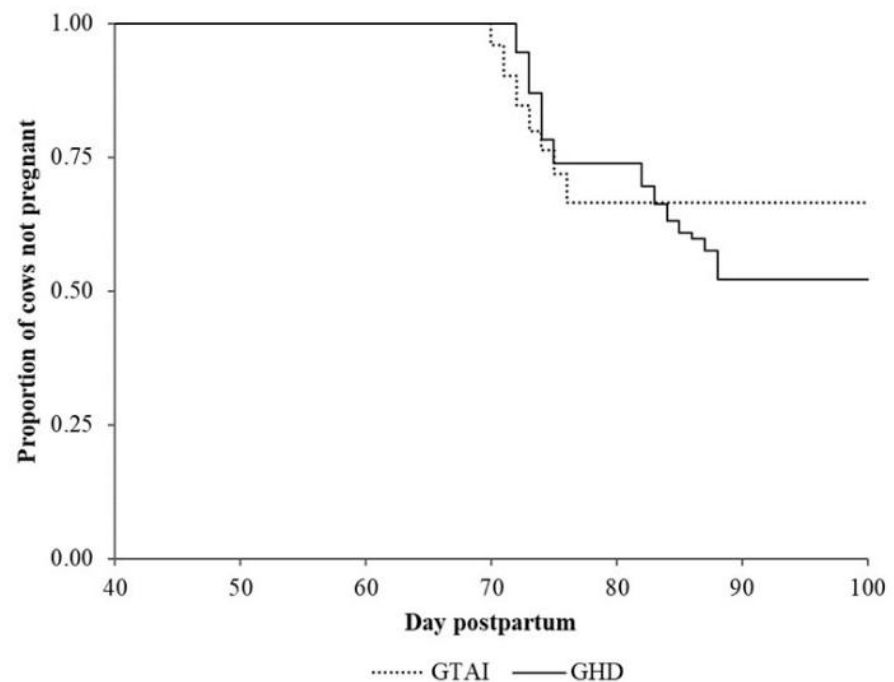

Figure 2. Kaplan-Meier survival curves for the proportion of cows not pregnant at 100 DIM in groups GTAI and GHD. Median days to pregnancy was $73 \mathrm{~d}$ for GTAI (95\% confidence interval (CI) 71-75) and $75 \mathrm{~d}$ for GHD (95\% CI 73-84). The rate of becoming pregnant was equal for GTAI compared to GHD (hazard ratio 1.4; 95\% CI 0.9-2.0, P = 0.11).

\section{Discussion}

The results from the present study showed no differences between the efficiency of G5D and G7D TAI protocols for the first p.p. service. These findings agree with previous research, where similar P/AI was noted when comparing a 5D vs. a 7D Ovsynch protocols plus PRID for the resynchronization of dairy cattle [7]. Santos et al. [10], had previously detected an increment in P/AI in 5D compared to 7D TAI protocol. However, in this research, cows were submitted to AI at the same time of the second GnRH treatment (CoSynch) and only one injection of PGF2 $\alpha$ was applied during the 7D CoSynch protocol. These differences in the study design could support the existing discrepancies. To our 
knowledge, there is no previous research comparing the efficiency of the $5 \mathrm{D}$ and 7D Ovsynch + PRID protocol in lactating dairy cows submitted to first service. Considering the above, it seems that reducing 2 days the interval from GnRH to the PGF2 $\alpha$ treatment has no effect on follicle dominance and consequently P/AI, provided that an exogenous progestogen and an additional PGF2 $\alpha$ treatment $24 \mathrm{~h}$ later are administered. Decreasing the duration of the TAI protocol from 10 to 8 days could have a significant economic impact especially in large farms. However, the " $5 \mathrm{D}$ plus progesterone" protocol appears to be more complicated in terms of compliance compared to the "7D plus progesterone" protocol, in which more treatments are applied at the same day of the week. Overall, only primiparous cows tended to show better P/AI compared to multiparous cows. Moreover, this effect was apparent both in the comparison of the 2 TAI protocols, as well as when group HD was added. This result was expected as synchronization rates and fertility are generally superior in first parity cows $[14,15]$ probably due to lower milk production, dry matter intake and steroid metabolism.

The initiation of conventional Ovsynch during days 5 to 9 of the estrus cycle, when $\mathrm{P} 4$ concentration is expected to be elevated and a dominant follicle is likely present in the ovaries, increases the proportion of cows that ovulate in response to the first $\mathrm{GnRH}$ injection [11], which in turn promotes better synchronization rate and fertility [12]. Furthermore, low $\mathrm{P} 4$ concentrations during the initiation of an Ovsynch protocol impairs both synchronization [15] and fertility [16]. Cows included in our research, exhibited the same fertility regardless of P4 concentration at the initiation of G5D and G7D protocols. This could be attributed to the PRID supplementation, as fertility is improved with augmented concentrations of P4 present during the luteal phase, prior to PGF2 $\alpha$ administration [17-20]. Moreover, the additional PGF2 $\alpha$ treatment, $24 \mathrm{~h}$ after the first one, seems necessary for complete luteolysis, as found by the high number (78 out of 98) of cows with luteal activity one day after the initial administration. The need of a second PGF2 $\alpha$ treatment for successful luteolysis agrees with previous research that has validated this hypothesis [21]. However, even after the second PGF2 $\alpha$ treatment, there was a considerable number of cows with high progesterone $(>1 \mathrm{ng} / \mathrm{mL}$ ) at $\mathrm{AI}$ (16 out of 98 ) and with no decrease of $\mathrm{P} 4$ concentration (12 out of 98) between the two measurements (at the time of the first PGF2 $\alpha$ treatment and at AI). Moreover, Vasconcelos, et al. [11], detected LA at AI in 15\% of cows that initiated TAI protocol during early diestrus (days 5 to 9 ). Incomplete luteolysis was not influenced by parity nor milk yield, although, season seems to have a mild negative effect. The negative effect of elevated P4 on P/AI is well studied, and it has motivated researchers to develop innovative drug delivery systems, aiming an intermittent release of luteolytic doses of PGF, that mimic natural endometrial prostaglandin secretion [22].

The group HD exhibited better P/AI compared to TAI group. This is a logical consequence, since cows assigned to the HD group were first pre-synchronized to enhance estrus expression and then, had two opportunities to be inseminated (one after HD and one after failure of HD and application of a 5D TAI protocol). The insemination in almost $50 \%$ of the HD group was delayed, since many cows conceived after TAI. However, median days to pregnancy did not differ between GHD and GTAI (73 vs. 75 days). As a result, we believe that the combination of synchronization protocols with intermediate heat detection can lead to good fertility outcomes. Regarding P/AI, an interaction between season and treatment was evident. Based on the results (presented on Table 3), the lower $\mathrm{P} / \mathrm{AI}$ in TAI group during winter was rather unexpected. Based on a further analysis we performed (data not shown), it was mainly attributed to the very disappointing P/AI (of only $7 \%$ ) of low yielding multiparous cows of group TAI during winter. Typically, cows with low milk production have better reproductive efficiency [23,24]. However, in this case, we hypothesize that low milk yield could have the same underlying cause with low P/AI, which could be the severe winter conditions experienced during part of the experimental period [25]. The augmented levels of P4, observed in TAI group after PRID removal and first PGF2 $\alpha$ administration, could be ascribed to a possible delayed clearance of progestogen originating from the PRID supplementation [26]. 
The results of the present study reveal that within the HD group, more primiparous cows exhibited estrus signs compared to multiparous cows, as it was expected [27]. Primiparous cows produce less milk [28] which promotes estrus expression [29]. Furthermore, low P4 at initiation of the synchronization protocol (day 63 of HD group) enhanced the detection of estrus. Probably, this was due to the presence of a young CL during that time, which responded well to the luteolytic effect of the second PGF2a treatment seven days later, as well as to the presence of young follicles able to produce sufficient amounts of estradiol and consequently, promote heat expression [30,31]. Based on this finding, if $\mathrm{HD}$ is a part of the reproductive management, the initiation of the G7G modified protocol should take place closer to the pre-synch protocol.

\section{Conclusions}

Only half of the cows in the HD group exhibited and were served after estrus. However, these cows were offered an immediate second chance of insemination and as a result they presented greater P/AI compared to solely TAI group. Additionally, this practice resulted in no difference regarding median days to pregnancy among all groups. Consequently, improving heat detection efficiency via investing in precise monitoring technologies or by increasing the proportion of cows eligible to show estrous (by a presynchronization protocol) would probably improve fertility in dairy farms. Furthermore, primiparous cows tend to express estrus more efficiently and are excellent candidates for a reproductive management based on heat detection. However, if a TAI protocol is preferred for ovulation synchronization, " $5 \mathrm{D}$ plus progesterone" protocol seems to be equally efficient with "7D plus progestogen" protocol.

Author Contributions: Conceptualization, C.B., E.K. and G.T.; methodology, C.B., E.K. and G.T.; formal analysis, G.T.; investigation, C.B., E.K., A.P. and G.T.; resources, C.B., E.K., I.G., V.K. and G.T.; data curation, C.B. and G.T.; writing-original draft preparation, C.B., S.H., A.P. and G.T.; writing-review and editing, C.B., E.K., S.H., A.P., I.G., V.K. and G.T.; visualization, S.H. and G.T.; supervision, C.B.; project administration, C.B.; funding acquisition, C.B., I.G. and V.K. All authors have read and agreed to the published version of the manuscript.

Funding: This research was funded by CEVA Hellas, grant number 92927 Aristotle University of Thessaloniki research committee.

Institutional Review Board Statement: The study was conducted according to the guidelines of the Declaration of Helsinki and approved by the research ethics committee of the Aristotle University Thessaloniki (approval code: 219974/21 September 2021).

Data Availability Statement: Data sharing not applicable.

Acknowledgments: The authors thank the owners of the collaborating dairy farms for use of their facilities and cows. Our appreciation is extended to CEVA Hellas for providing Ovarelin, Cevaprost and PRID and funding this research.

Conflicts of Interest: IG and VK are employees of CEVA Hellas, that provided the medicaments and funded this study.

\section{References}

1. Sangsritavong, S.; Combs, D.K.; Sartori, R.; Armentano, L.E.; Wiltbank, M.C. High feed intake increases liver blood flow and metabolism of progesterone and estradiol-17beta in dairy cattle. J. Dairy Sci. 2002, 85, 2831-2842. [CrossRef]

2. Pursley, J.R.; Wiltbank, M.C.; Stevenson, J.S.; Ottobre, J.S.; Garverick, H.A.; Anderson, L.L. Pregnancy rates per artificial insemination for cows and heifers inseminated at a synchronized ovulation or synchronized estrus. J. Dairy Sci. 1997, 80, 295-300. [CrossRef]

3. Ribeiro, E.S.; Cerri, R.L.; Bisinotto, R.S.; Lima, F.S.; Silvestre, F.T.; Greco, L.F.; Thatcher, W.W.; Santos, J.E. Reproductive performance of grazing dairy cows following presynchronization and resynchronization protocols. J. Dairy Sci. 2011, 94, 4984-4996. [CrossRef] [PubMed]

4. Carvalho, P.D.; Guenther, J.N.; Fuenzalida, M.J.; Amundson, M.C.; Wiltbank, M.C.; Fricke, P.M. Presynchronization using a modified Ovsynch protocol or a single gonadotropin-releasing hormone injection $7 \mathrm{~d}$ before an Ovsynch-56 protocol for submission of lactating dairy cows to first timed artificial insemination. J. Dairy Sci. 2014, 97, 6305-6315. [CrossRef] 
5. Souza, A.H.; Ayres, H.; Ferreira, R.M.; Wiltbank, M.C. A new presynchronization system (Double-Ovsynch) increases fertility at first postpartum timed AI in lactating dairy cows. Theriogenology 2008, 70, 208-215. [CrossRef] [PubMed]

6. Pursley, J.R.; Mee, M.O.; Wiltbank, M.C. Synchronization of ovulation in dairy cows using PGF2alpha and GnRH. Theriogenology 1995, 44, 915-923. [CrossRef]

7. Santos, V.G.; Carvalho, P.D.; Maia, C.; Carneiro, B.; Valenza, A.; Crump, P.M.; Fricke, P.M. Adding a second prostaglandin F2alpha treatment to but not reducing the duration of a PRID-Synch protocol increases fertility after resynchronization of ovulation in lactating Holstein cows. J. Dairy Sci. 2016, 99, 3869-3879. [CrossRef] [PubMed]

8. Wiltbank, M.C.; Baez, G.M.; Cochrane, F.; Barletta, R.V.; Trayford, C.R.; Joseph, R.T. Effect of a second treatment with prostaglandin F2alpha during the Ovsynch protocol on luteolysis and pregnancy in dairy cows. J. Dairy Sci. 2015, 98, 8644-8654. [CrossRef]

9. Colazo, M.G.; Dourey, A.; Rajamahendran, R.; Ambrose, D.J. Progesterone supplementation before timed AI increased ovulation synchrony and pregnancy per AI, and supplementation after timed AI reduced pregnancy losses in lactating dairy cows. Theriogenology 2013, 79, 833-841. [CrossRef]

10. Santos, J.E.; Narciso, C.D.; Rivera, F.; Thatcher, W.W.; Chebel, R.C. Effect of reducing the period of follicle dominance in a timed artificial insemination protocol on reproduction of dairy cows. J. Dairy Sci. 2010, 93, 2976-2988. [CrossRef]

11. Vasconcelos, J.L.; Silcox, R.W.; Rosa, G.J.; Pursley, J.R.; Wiltbank, M.C. Synchronization rate, size of the ovulatory follicle, and pregnancy rate after synchronization of ovulation beginning on different days of the estrous cycle in lactating dairy cows. Theriogenology 1999, 52, 1067-1078. [CrossRef]

12. Bello, N.M.; Steibel, J.P.; Pursley, J.R. Optimizing ovulation to first GnRH improved outcomes to each hormonal injection of ovsynch in lactating dairy cows. J. Dairy Sci. 2006, 89, 3413-3424. [CrossRef]

13. Mayo, L.M.; Silvia, W.J.; Ray, D.L.; Jones, B.W.; Stone, A.E.; Tsai, I.C.; Clark, J.D.; Bewley, J.M.; Heersche, G., Jr. Automated estrous detection using multiple commercial precision dairy monitoring technologies in synchronized dairy cows. J. Dairy Sci. 2019, 102, 2645-2656. [CrossRef]

14. Balendran, A.; Gordon, M.; Pretheeban, T.; Singh, R.; Perera, R.; Rajamahedran, R. Decreased fertility with increasing parity in lactating dairy cows. Can. J. Anim. Sci. 2008, 88, 425-428. [CrossRef]

15. Forro, A.; Tsousis, G.; Beindorff, N.; Sharifi, A.R.; Brozos, C.; Bollwein, H. Factors affecting the success of resynchronization protocols with or without progesterone supplementation in dairy cows. J. Vet. Sci. 2015, 16, 121-126. [CrossRef] [PubMed]

16. Bisinotto, R.S.; Chebel, R.C.; Santos, J.E. Follicular wave of the ovulatory follicle and not cyclic status influences fertility of dairy cows. J. Dairy Sci. 2010, 93, 3578-3587. [CrossRef] [PubMed]

17. Bisinotto, R.S.; Lean, I.J.; Thatcher, W.W.; Santos, J.E. Meta-analysis of progesterone supplementation during timed artificial insemination programs in dairy cows. J. Dairy Sci. 2015, 98, 2472-2487. [CrossRef]

18. El-Zarkouny, S.Z.; Cartmill, J.A.; Hensley, B.A.; Stevenson, J.S. Pregnancy in dairy cows after synchronized ovulation regimens with or without presynchronization and progesterone. J. Dairy Sci. 2004, 87, 1024-1037. [CrossRef]

19. Stevenson, J.S.; Pursley, J.R.; Garverick, H.A.; Fricke, P.M.; Kesler, D.J.; Ottobre, J.S.; Wiltbank, M.C. Treatment of cycling and noncycling lactating dairy cows with progesterone during Ovsynch. J. Dairy Sci. 2006, 89, 2567-2578. [CrossRef]

20. Walsh, R.B.; Leblanc, S.J.; Duffield, T.F.; Kelton, D.F.; Walton, J.S.; Leslie, K.E. The effect of a progesterone releasing intravaginal device (PRID) on pregnancy risk to fixed-time insemination following diagnosis of non-pregnancy in dairy cows. Theriogenology 2007, 67, 948-956. [CrossRef]

21. Ribeiro, E.S.; Bisinotto, R.S.; Favoreto, M.G.; Martins, L.T.; Cerri, R.L.; Silvestre, F.T.; Greco, L.F.; Thatcher, W.W.; Santos, J.E. Fertility in dairy cows following presynchronization and administering twice the luteolytic dose of prostaglandin F2alpha as one or two injections in the 5-day timed artificial insemination protocol. Theriogenology 2012, 78, 273-284. [CrossRef]

22. Masello, M.; Ren, Y.; Erickson, D.; Giordano, J.O. An automated controlled-release device for intravaginal hormone delivery. J. Dairy Sci. 2020, 1, 15-20. [CrossRef]

23. Melendez, P.; Pinedo, P. The association between reproductive performance and milk yield in Chilean Holstein cattle. J. Dairy Sci. 2007, 90, 184-192. [CrossRef]

24. Windig, J.J.; Calus, M.P.; Veerkamp, R.F. Influence of herd environment on health and fertility and their relationship with milk production. J. Dairy Sci. 2005, 88, 335-347. [CrossRef]

25. Gwazdauskas, F.C. Effects of climate on reproduction in cattle. J. Dairy Sci. 1985, 68, 1568-1578. [CrossRef]

26. Cerri, R.L.; Rutigliano, H.M.; Bruno, R.G.; Santos, J.E. Progesterone concentration, follicular development and induction of cyclicity in dairy cows receiving intravaginal progesterone inserts. Anim. Reprod. Sci. 2009, 110, 56-70. [CrossRef] [PubMed]

27. Madureira, A.M.L.; Silper, B.F.; Burnett, T.A.; Polsky, L.; Cruppe, L.H.; Veira, D.M.; Vasconcelos, J.L.M.; Cerri, R.L.A. Factors affecting expression of estrus measured by activity monitors and conception risk of lactating dairy cows. J. Dairy Sci. 2015, 98, 7003-7014. [CrossRef] [PubMed]

28. Friggens, N.C.; Emmans, G.C.; Veerkamp, R.F. On the use of simple ratios between lactation curve coefficients to describe parity effects on milk production. Livest. Prod. Sci. 1999, 62, 1-13. [CrossRef]

29. Lopez, H.; Satter, L.D.; Wiltbank, M.C. Relationship between level of milk production and estrous behavior of lactating dairy cows. Anim. Reprod. Sci. 2004, 81, 209-223. [CrossRef]

30. Allrich, R.D. Endocrine and neural control of estrus in dairy cows. J. Dairy Sci. 1994, 77, 2738-2744. [CrossRef]

31. Fortune, J.E.; Rivera, G.M.; Evans, A.C.; Turzillo, A.M. Differentiation of dominant versus subordinate follicles in cattle. Biol. Reprod. 2001, 65, 648-654. [CrossRef] [PubMed] 